\title{
Analysis on Dormitory Safety Education for Contemporary College Students
}

\author{
Jianwei Ma \\ Tianjin University of Finance and Economics, Tianjin, China
}

Keywords: safety education; college students; dormitory

\begin{abstract}
Dormitory safety management is an important issue in campus. To ensure the safety of students' dormitory, it is necessary to improve the safety awareness of students, focus more on the practice of dormitory safety management, give full play to the subjective initiative of students, and constantly improve the external environment.
\end{abstract}

\section{The Main Characteristics of College Students}

\subsection{The ideology}

Mostly contemporary college students are "post-90s". They live in the important period of information development and enjoy a convenient life with easy access to kinds of things every day. Some of the information, they get, is for their daily study and appropriate recreation, which is conducive to enhancing their own abilities, and becomes a gossip for talking to each other. Other information may make them get into some bad habits from the Internet and even make them become the victims of the transmission of bad information. All above will change the thoughts of "post-90s" and force them to have different ways of cognition and behaviors from those of their predecessors.

\subsection{The character}

Most "post-90s" are the only child in their family, living in relatively superior conditions, who grow up under the care of parents. So they don't need to scruple others' feelings, and therefore they have a strong self-awareness. At the same time, "post-90s" contact closely with the society. They are relatively premature when handling problems, but their experience of failures is relatively few. Therefore, once they encounter a setback, they can't accept in a short time. More importantly, influenced by the Internet culture, contemporary "post-90s" are willing to accept new things, but they scoff at the old things, which is called 'be fickle in affection'.

\subsection{In study}

University is different from primary and secondary schools, "post-90s" do not need teachers and parents to urge themselves to learn. The way of learning is changing from passive to active, which makes college students that just left their secondary schools unable to master the skill of self-learning. However, to develop the habit of self-learning is of great help to the future, which needs their own improvement and guidance from other people. According to their own learning habits step by step, they will finally be able to truly grasp the skills of self-learning. Although contemporary college students possess better learning resources, they cannot make good use of them.

\section{Factors that Affect Safety of College Students}

\subsection{External factors}

The social environment around the universities is complex, and the degree of the school's behaviors to protect schools from infiltration is different, which leads to the existence of external security risks of universities. At the same time, the security awareness of supervisors of dorms and the university students themselves is different, which gives chances to criminals and leads to the frequent occurrence of the vicious incidents of security violations in recent years. 


\subsection{Internal factors}

The low degree of recognition of these problems among students and school administrators is also one of the main factors that affect safety. Some college students think that these kinds of thing will not happen on themselves. Therefore, they neglect the serious consequences of these incidences. At the same time, the university students lack the knowledge of safety. They do not know how to use the fire extinguisher, making the fire extinguisher a decoration at emergency. Moreover, the administrators are irresponsible. They don't impart the safety knowledge to the students on a regular basis. They can't help and even pass the buck to the criminals after the accidence.

\section{The Way of Safety Education in Contemporary Colleges and Universities}

\subsection{Carry out related lectures on safety education}

This is the most common way of secure education in schools. Schools will invite some professional people who know more about firefighting, public security and first aid to come to their school and carry out propaganda of safety regularly. This kind of face-to-face teaching enables students to learn more, and the demonstration in the field will give students more direct contact and get better use of knowledge.

\subsection{Carry out volunteer activities on safety education}

This method improves spiritual civilization of the college students and the spirit of volunteerism in the university. These activities provide students with the opportunities to express themselves make the students get exercise and accumulate experience of volunteer activities, and increase their chances of social communications, which are important component of safety education in colleges and universities.

\subsection{Establish the security leadership group in colleges and universities}

This way belongs to institutional level. It implements the main responsibility of the school safety management, improves the frequency of daily safety education and the scientificity of the emergency treatment, and guarantees the foundation of school security work from the organizational systematic level. At the same time, school also signs up all kinds of safety regulations with the students, parents and teachers, which makes the teachers and students improve their sense of responsibility and the awareness of unexpected accidences. All these guarantee the normal work of the school and the physical and mental healthy growth of students.

\section{Problems of Safety Education in Contemporary Colleges and Universities}

\subsection{More focus on theory and less practice}

Nowadays many universities did not carry out activities except the traditional outside safety-education practice. As a direct result, students only have theoretical knowledge, but do not have actual actions at emergency. They can't identify the situation and don't know how to make respond. Additionally, the related functionary is irresponsible. They treat the condition carelessly and they don't teach students how to prevent and rescue themselves from accidences. Therefore, this is not only an important issue for the safety education of contemporary college students, but also an important challenge for the university to put the knowledge of non-traditional security education into reality.

\subsection{Lack of the subjective initiative of students}

At present, the safety education of various colleges and universities only impart safety knowledge to the students, and the students only accept passively. As the saying goes, 'It's better to teach a man fishing than to give him fish'. Just teach students the fact that the safety problem accounts for the unawareness of students and functionaries and some other reasons, and then talk about several fixed methods to prevent danger in the crisis is not enough. Because each use of electric appliance is not 
exactly the same, and the motivations of criminals are also different, so the concrete analysis will be adopted with the specific situations. To let students learn about the security problems which have been or will appear, schools should encourage students to find a suitable solution according to different situation. Therefore, it is the primary task to find the key point of the problem and follow the fundamental governance.

\subsection{The deviation in students' own knowledge of safety education}

Safety education itself is a very serious problem, so the students' attitude to it should be upright. But most students think that this kind of safety education is dull, and they think that they know these things so the education is useless. Therefore, they have slack meaning of safety education and don't know that hidden trouble is the bottom line to the accident. Some students think that they can only find police when stolen or robbed and ask fire protection when fire is on. They don't have any preproduction themselves and consider the hurt of body is inevitable. If this negative concept has not been changed, the effect of school's security education is very limited.

\subsection{The interference from external environment in students' learning about related education}

This is mainly about the impact of the network environment on security education. This is an era of high speed information, college students are exposed to a variety of information every day on the Internet, but the information on the network is different. Good information help improve all their aspects when bad information will have a negative impact on the students. What's worse, it will enable students to immerse in that and contact fewer with reality, which leads to the ignorance of students' safety education. Therefore, to strengthen the network security education will help college students to learn about safety education indirectly.

\section{The Improvement Direction of Safety Education in Contemporary Colleges and Universities}

\subsection{Change the useless theory of safety education}

The safety education of the school should change the traditional concept and set up a big security view. Along with the rapid development of China's economy, the social order is stable, our life is getting better, but new problems with the development of the society always exists. Therefore, we need to establish a nontraditional security concepts to make our society more stably and unite. Meanwhile, colleges and universities should be fully aware of the long-term significance of non-traditional safety education, make greater efforts to carry out safety education activities in schools, change the traditional way of education, and let students truly understand that safety education is the primary task of university education.

\subsection{Broaden the scope of knowledge of safety education}

Today's college students are affected by a number of new security factors, such as finance, ecology, information, psychology, network security and other new aspects. In recent years, there have been frequent cases of SMS fraud, intellectual property infringement, and infringement of consumer rights and interests among college students. Therefore, apart from the fire safety knowledge, the crime prevention, emergency and other aspects, students should also get new safety knowledge and master the skills of these safety aspects to enhance security capabilities of their own and to improve their comprehensive quality. Therefore, to broaden the scope of the knowledge of safety education is also an urgent task for the improvement of the university education.

\subsection{Cultivate students' ability to carry out safety education independently}

It is also important for students to learn independently. This way is compared to passive learning which can give full play to the students' subjective initiative. When students impart safety knowledge to others, it is also a study for themselves, because only when you understand this knowledge totally, will you have a clear idea in the brain and make the other students follow your train of thought to have a general understanding. At the same time, each student learning style is not exactly the same, different ways create more space for students to have more understanding ways. Through this 
platform, students benefit from mutual discussion and communication, and gain more achievements. This way of training is not only about students' learning ability, but also a training of students' ability of communication and language expression. What's more, it is the comprehensive quality of students. So it is a very effective way and the safety education of contemporary college students should be considered in this way.

\subsection{Pay attention to practice}

Practice is the only criterion for testing truth. The nontraditional security education only presents the basic theory, but does not really apply to daily life. But how to put nontraditional security education knowledge into practice is a big problem faced by the safety education of college students, because this knowledge is more abstract. It is difficult to express with action which need to contact with the associated objects to turn the abstract into concrete. It facilitates students' understanding and grasp. At the same time, colleges and universities should hold safety drills and practice, so that students can really learn. This is also a very important link in the safety education of today's college students.

\section{References}

[1] Y.F. Zhao, College student dormitory safety management, J. Journal of Hebei Energy Institute of Vocation and Technology. 2 (2009).

[2] H. Zhu, X.Y. Du, Problems and countermeasures about the safety management of college student dormitories, J. Time Education. 6 (2011).

[3] L.L. Yang, Reflections on the safety of college student dormitories, J. Journal of Jiamusi Education Institute. 2 (2010)

[4] J.F. Hu, Analysis on potential safety hazard in college student dormitories and countermeasures, J. Journal of Guangdong Baiyun University. 4 (2007). 